\title{
Experimental Investigation of Photovoltaic Partial Shading Losses under Different Operation Conditions
}

\author{
Ali. H. Numan ${ }^{1}$, Zahraa S. Dawood ${ }^{2 *}$, Hashim A. Hussein ${ }^{3}$
}

Authors affiliations:

$1 *)$ Department of

Electromechanical

Engineering, University of

Technology, Baghdad, Iraq

$\left.2^{*}\right)$ Department of

Electromechanical

Engineering, University of

Technology, Baghdad, Iraq

Zahraasalman777@gmail.com

3) Department of

Electromechanical

Engineering, University of

Technology, Baghdad, Iraq

\section{Paper History:}

Received: $14^{\text {th }}$ Oct. 2019

Revised: 14 ${ }^{\text {st }}$ Dec. 2019

Accepted: 29th Jan. 2020

\begin{abstract}
:
The partial shading conditions have a significant effect on the performance of Photovoltaic system and the ability of delivering energy. In this study, the impact of different partial shading on the mono crystalline (88W) PV module performance was investigated in this study. Horizontal string, vertical string, and single cell shading at different percentage of shading area have been studied. It is found that the horizontal string shading is more severe on the efficiency of the PV panel. In contrast, the efficiency of PV panel with cellular and vertical cell shading was less during the tests. The experimental results showed that the power losses were $99.8 \%, 66 \%$ and $56.8 \%$ for horizontal, cellular and vertical shading respectively via applied non transparent material as shading element by $100 \%$ of shading area at $500 \mathrm{~W} / \mathrm{m}^{2}$. Moreover, transparent material used to shade whole module horizontally, different shading area and different radiation level applied to find electrical characteristics of the module under these conditions. The results show that at $800 \mathrm{~W} / \mathrm{m}^{2}$ of irradiation levels and no shading condition the power was 68.6W, by increase shading area by $20 \%$ in each step, the power reducing by $44.94,47.58,49.42,50.57$ and $52.4 \%$ in compared with their initial value at no shading condition.
\end{abstract}

Keywords: PV Module, Partial Shading, Electrical Efficiency, Quick Sun System

$$
\begin{aligned}
& \text { التحقيق التجريبي في خسائر التظليل الجزئي للوحدةالكهروضوئية تحت ظروف التشغيل } \\
& \text { مختلفة } \\
& \text { علي حسين نعهان، زهراء سلمان داود، هاشم عبد حسين }
\end{aligned}
$$

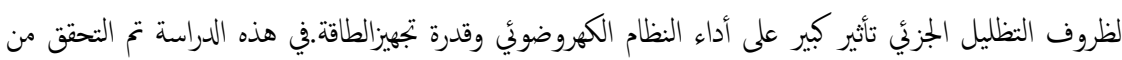

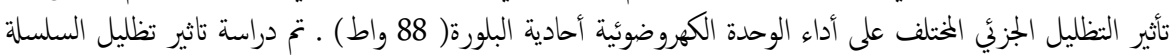

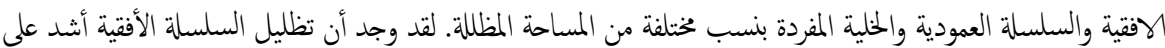

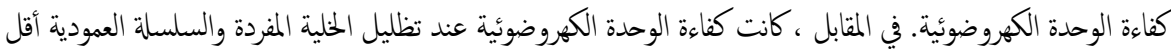

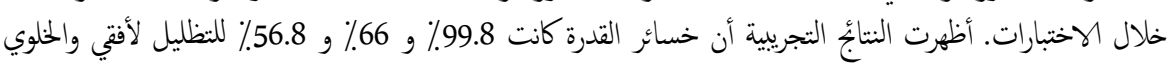

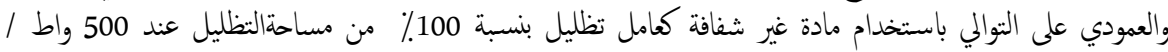

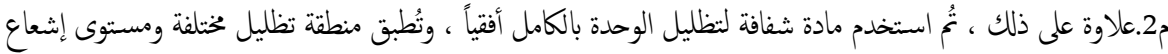

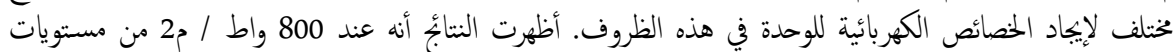

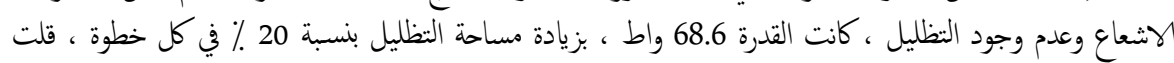

$$
\begin{aligned}
& \text { القدرة بنسبة } 44.94 \text { ، } 47.58 \text { ، } 49.42 \text { ، } 50.57 \text { و } 58.6 \text { و } 52.4 \text { ٪ مقارنة مع الثميمة الأولية في حالة عدم التظليل. }
\end{aligned}
$$

\section{Introduction}

The increase of human population from one hand and the development of technologies worldwide from other represent the main causes for increasing demand on electricity which lead to depletion the fossil fuels such as gas, oil, and coal. The problem of carbon emissions such as Carbon dioxide, Nitrous oxide, Methane Chlorofluro carbon and Ozone, which result from the traditional electrical power generation, representing one of the most important reasons that lead to employed the renewable energy as alternative mode of electrical power generation.

NJES is an open access Journal with ISSN 2521-9154 and eISSN 2521-9162

This work is licensed under a Creative Commons Attribution-NonCommercial 4.0 International License 
Sustainable or renewable energy, such as hydroelectricity, solar and wind represent the best solution for clean energy without emissions. [1-2].

Solar energy is the best option for electricity generation because it is clean source less expensive, silent and environmental friendly[3-4], alternative energy source which is not exhaustible and can be utilized for power generation in remote areas. The utilization of solar energy can be classified in two ways: solar electricity and solar heating/cooling[5]. A PV cell is basically a semiconductor diode with a large barrier layer exposed to light allowing portion of the energy in the light photons arriving at the cell convert directly to DC electrical power [6]. The most notable factors that have a clear impact on the performance of PV system are: Partial shading, dust, temperature, solar radiation and sand[4],[7]

Partial shading is the most common encountered problem in a PV system, in this phenomenon the sunlight received is reduced significantly and resulting in lower system efficiency In the design stage, the shadow of nearby objects avoided as possible. However, parts of PV module suffer from unexpected shadows such as, unmelted snow, bird dung, fallen leaves, antennas, telephone poles ,and so forth [8-10]. The short circuit current value of the cells is depended on the irradiance level; therefore, under this condition (partial shading PS) the unshaded cells generate high current while the shaded cells producing less current. In the series-connected cells, the current must be similar through all the cell of the string; therefore, non _uniform illuminated cells as a result operates in the reverse bias region to conduct the major current of the un shaded cells [11]. The dangerous of the reverse biasing of the solar cell based on the $(\mathrm{I}-\mathrm{V})$ characteristic of the $\mathrm{p}-\mathrm{n}$ junction which is affected by the breakdown voltage (BV) and the shunt resistance (Rsh). The breakdown voltage can be defined as the maximum pliable reverse voltage for the secure working of the junction; close to this voltage caused a large rise of the reverse current and finally to destroy the equipment. Shunt resistance depict undesired current paths along the cell edges or during the inherent cell diode when the current passing in the shunt resistance causes power loss and, then, heating the cell. The reverse voltage appearing in both cases limits the quantities of degenerated power and temperature of the PV cell [12].

H. H. Khaing et al (2014) [13]: Studied the effect of different partial shading on four various types of PV modules that involve amorphous thinfilm, CIGS thin-film, CdTe thin-film and multicrystalline PV modules. The module tested along the length side and along the breadth side with different shading rate varied from $10 \%$ to $60 \%$ from the PV area with increase of $10 \%$. The result showed that shading along the breadth side more effected than shading along its length side. In addition, the result from length side shading showed that a-Si module gave better results followed by $\mathrm{CdTe}, \mathrm{mc}-\mathrm{Si}$ with bypass diode, CIGS and mc-Si without bypass diode respectively. The a-Si module maintaining its power output till $70 \%$ of shaded area. While the power output in $\mathrm{CdTe}$ and $\mathrm{mc}-\mathrm{Si}$ with bypass diode maintaining until $60 \%, 12 \%$ of module shaded area respectively. The CIGS, mc-Si without bypass diode stop there output at $30 \%, 10 \%$ of shaded area. From the other hand, the experimental results from breadth side shading showed that a-Si keeps the highest allowance to the shadow until $50 \%$, followed by CdTe and CIGS till 30\%. While, Mc-Si until 10\% shaded area. F. Bayrak et al. (2017) [14]: Investigated thermodynamic and electrical performance under the shading shape and shading ratios on polycrystalline PV panel which have $75 \mathrm{~W}$ power. Horizontal, vertical and single cell shading at different percentage were applied. The results showed that at $100 \%$ shading rate, the power losses were $99.98,66.93$ and $69.92 \%$ for horizontal, vertical and cellular shading. M. Abdullah et al (2017) [15]: Investigated the impact of shading on the effectiveness of PV panel. The experiments have been accomplished with a 90- W solar panel under constant and changeable irradiations. Horizontally shaded area rise from 0 to $80 \%$ has been applied to detect the impact of varying irradiation at appointed shading points. The results showed that for each $100 \mathrm{~W} / \mathrm{m}^{2}$ increase in radiation level lead lo enhanced the output power by $3.89,3.37,2.27$, and $2.02 \mathrm{~W}$ at 0 , 25,50 , and $75 \%$ shaded area respectively. The drop in output power and efficiency were $12.41 \mathrm{~W}$ and $2.3 \%$ respectively when the shading area increased by $10 \%$.

In the present paper, different cases of partial shading with different percentages investigated to determine its impact on power and electrical efficiency of mono crystalline PV panel. This works were done in Al- Mansour Company, Baghdad. Quick sun system employed to report the I-V and P$\mathrm{V}$ characteristic curves before and after applying shading. Insulated material employed as shading element in different cases with different percentage of shaded area. Moreover, transparent material employed to shade whole the panel horizontally with different percentage of shaded area to study horizontal shading impact on the electrical characteristic of the PV panel.

\section{Research method}

\subsection{Description of solar simulator (Quick sun 700A)}

Experiments were carried out in the solar panel laboratory (Quick sun 700A) of AL-Mansour Company in Baghdad. Monocrystalline $(9 * 4$ cell $)$ module (ZAHRAA S. D.) used in experiment to obtain the results. Table 1 explains the electrical characteristics of the Mono-crystalline solar panel. The Quick sun system components which used to measure electrical performance of Photovoltaic modules are shown in Figure1. Quick sun system processes the measurement data and presents the result graphically as well as by showing key information on the electrical performance of module as shown in Figure 2. The IV characteristics of large and small size PV modules can be measured by this system whether they are made of crystalline or thin 
film material. The proprietary working precept supports straightforward series resistance estimation according to the IEC891 method and weak light IV characteristics measurements at any desired irradiance level. Quick sun software work in Windows XP environments, and has a graphical user interface. It communicates with the electronic unit and the optional barcode scanner using serial communications port. A printer may be used to produce print outs of the measurement results. It consist of number of unit, some of these units are set inside the black box such as flash system and control unit. While computer system set outside the black box. The box painted by black color to prevent reflection of irradiation.

Table 1: Electrical Characteristic of Monocrystalline solar panel

\begin{tabular}{|lc|}
\hline Maximum power (P max) & $88 \mathrm{~W}$ \\
Open circuit voltage $($ VOC $)$ & $23.42 \mathrm{~V}$ \\
Short circuit current $(I S C)$ & $5.192 \mathrm{~A}$ \\
Voltage at maximum power $(V m p)$ & $18.33 \mathrm{~V}$ \\
Current at maximum power $(\operatorname{Imp})$ & $4.801 \mathrm{~A}$ \\
Voltage temperature coefficient $(\mathrm{Kv})$ & $-2.10 \mathrm{mV} / \mathrm{cell} /{ }^{\circ} \mathrm{C}$ \\
Current temperature coefficient $(\mathrm{Ki})$ & $15 \mathrm{micro} \mathrm{A} / \mathrm{cm} 2 /{ }^{\circ} \mathrm{C}$ \\
No. of cells connected in series $(N S)$ & 36 \\
No. of cells connected in Parallel $(N P)$ & 1 \\
\hline
\end{tabular}

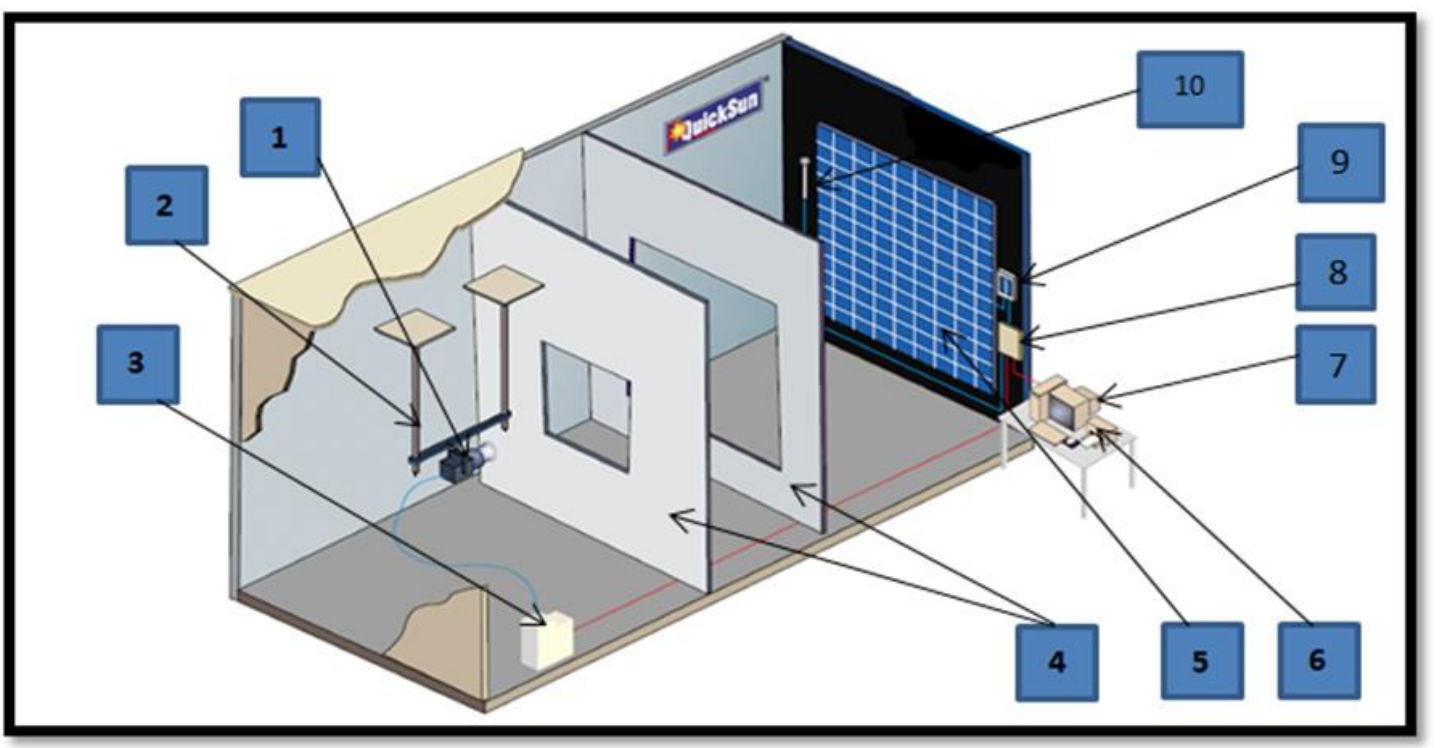

Figure 1: The components of Quick-sun system. (1-Halogen Lamp, 2- Lamp Head Housing, 3- Flash generator 4 aperture plates, 5-Fixing Wall, 6-Printer, 7-Computer system, 8-Electronics Units, 9-Monitor Cell, 10-Ambiant Temperature Sensor)

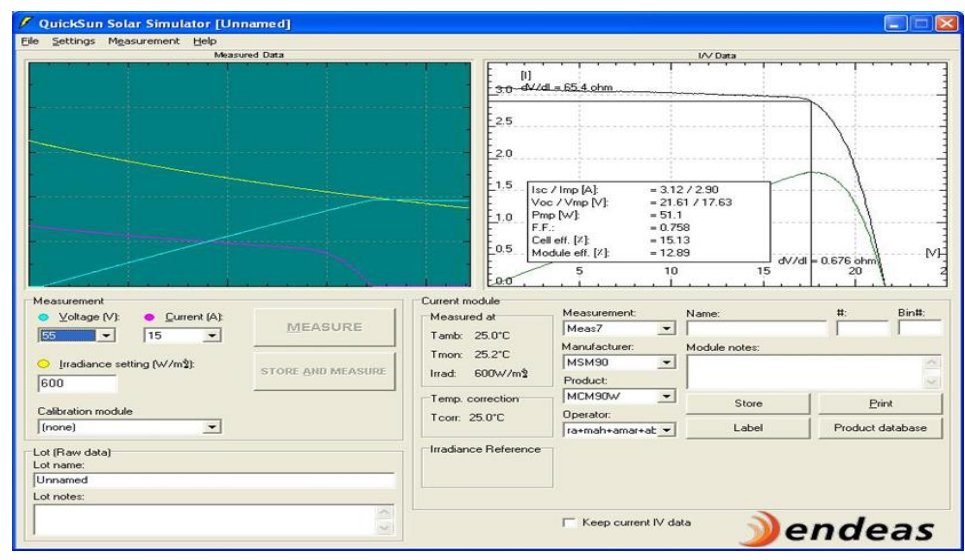

Figure 2: The results of test on the PC 


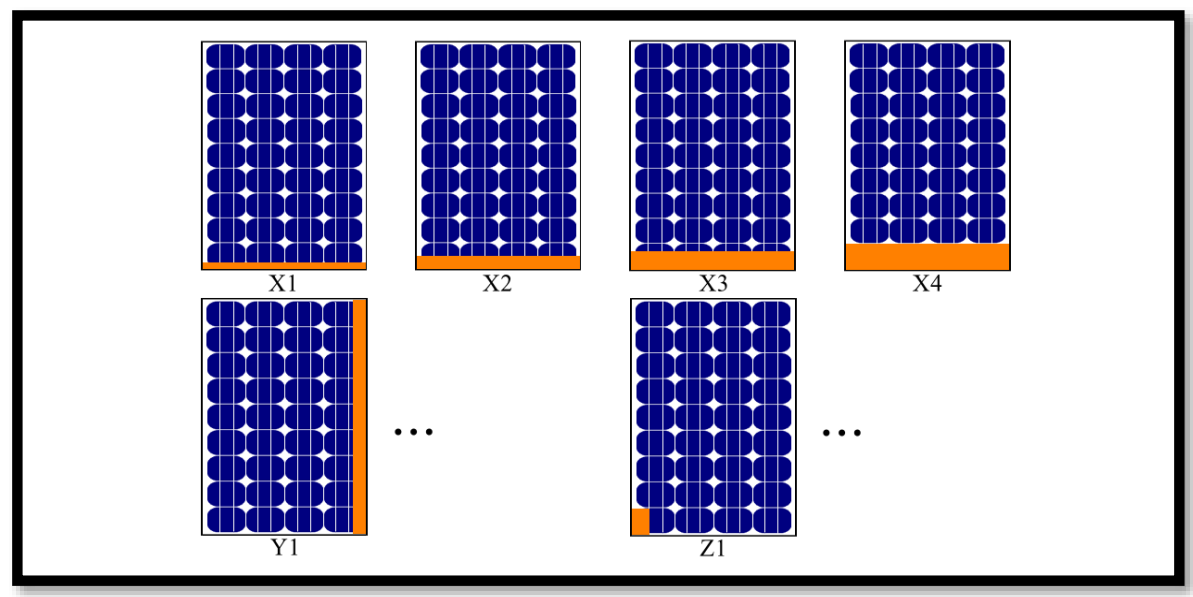

Figure 3: Different percentage of shading for horizontal, vertical and single cell by employed insulated materials; (X1) $\mathrm{SA}=25 \%$, (X2) $\mathrm{SA}=50 \%$, (X3) $\mathrm{SA}=75 \%$ and (X4) $\mathrm{SA}=100 \%$, (Y) SA=25\%, (Z1) $\mathrm{SA}=25 \%$.

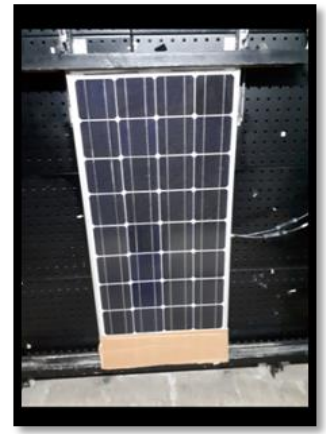

(A)

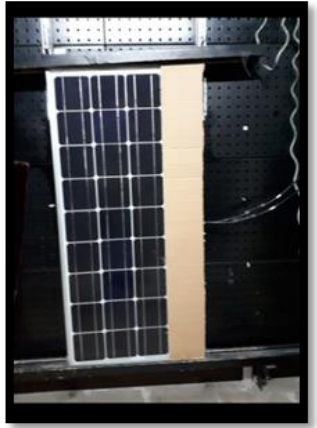

(B)

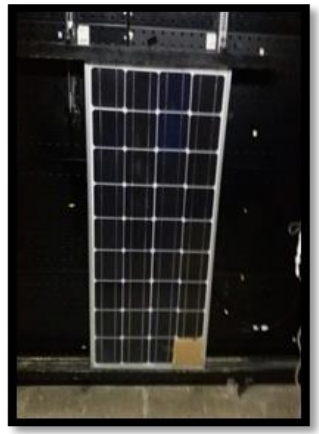

(C)

Figure 4: Different cases of PV panel shading (A) vertical string, (B) horizontal string, (C) Single cell

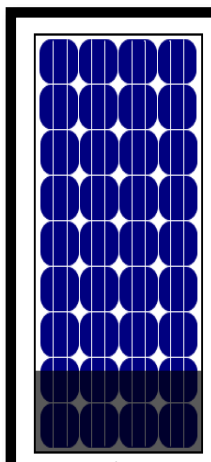

A

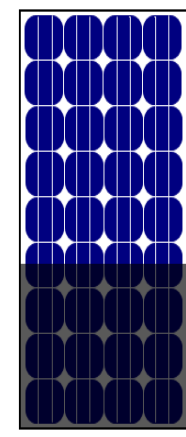

B

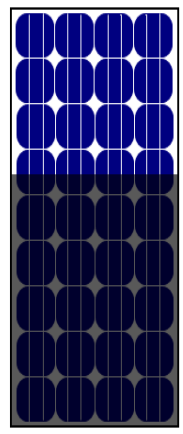

C

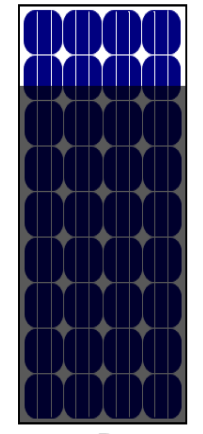

D

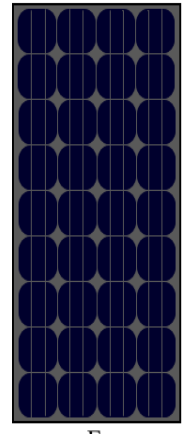

E

Figure 5: Horizontal panel shading with different percentage of shaded area by using transparent element shading (shading ratio 30\%); (A) $\mathrm{SA}=20 \%$, (B) $\mathrm{SA}=40 \%$, (C) $\mathrm{SA}=60 \%$, (D) $\mathrm{SA}=80 \%$ and (E) $\mathrm{SA}=100 \%$.

\subsection{Experimental procedure}

The current and voltage at the terminals of PV panel must be measured in order to find the I-V characteristic of the panel. Temperature and irradiance affected on these characteristic so, in this work, environment temperature sensing by LM35 sensor would kept constant at $25 \mathrm{C}$, while the irradiation from halogen lamp changed from 200 to $1000 \mathrm{~W} / \mathrm{m}^{2}$ to explain the impact of partial shading at different irradiation levels. Nontransparent material (cardboard) employed as shading element for Different cases (horizontal string, vertical string and single cell) with different percentage of shading ( 0 , $25,50,75$ and $100 \%$ of shaded area), as shown in Fig.3. In addition to that, transparent material used as shading element to cover whole panel horizontally with shaded area changed from $0 \%$ to $100 \%$ (each step with 20\%) as shown in Figure 5. Through Quick sun software, the irradiation level selected and then the tests are done. For each type of shading (cell, vertical string, and horizontal string) the $\mathrm{I}-\mathrm{V}$ and $\mathrm{P}-\mathrm{V}$ curves are recorded to analyse the influence of shading process applied on the PV panel. A measurement can be started by clicking the measure button in the measurement panel of the main 
window. This automatically triggers the Quick sun software, retrieves measurement data from the Quick sun electronics unit, performs temperature corrections, draws the graphs and computes key statics of the module performance.

\section{Results and discussion}

An experimental investigation to analyze the performance after applying shading was carried out based on shading ratio, there are three cases of shading with different shaded area are studied as clarified in Figure 3 and photo of Figure 4.

\subsection{Partial shading effect on power output}

The power output under partial shading as function of radiation for the cases of shading has been illustrated in Figures 6,7 and 8. It can be noticed that the power decreased when solar radiation decreased. In addition, the power adversely effected when the percentage of shading increased. Moreover, table 2. Cleared the result of different shading cases with different shading area at constant radiation levels is $500 \mathrm{~W} / \mathrm{m}^{2}$.

Table 2: Power and power Loss value of different shading.

\begin{tabular}{|c|c|c|c|c|c|c|}
\hline $\begin{array}{c}\text { Shading } \\
\text { Area }\end{array}$ & $\begin{array}{c}\text { Horizontal } \\
\text { string } \\
\text { Shading- } \\
\text { Case I }\end{array}$ & \multicolumn{2}{|c|}{$\begin{array}{c}\text { Vertical } \\
\text { string } \\
\text { Shading- } \\
\text { Case II }\end{array}$} & \multicolumn{2}{|c|}{$\begin{array}{c}\text { Single cell } \\
\text { Shading- Case } \\
\text { III }\end{array}$} \\
\hline SA & $\mathrm{P}$ & $\begin{array}{c}\text { P } \\
\text { losses } \\
\%\end{array}$ & $\mathrm{P}$ & $\begin{array}{c}\text { P } \\
\text { losses } \\
\%\end{array}$ & $\mathrm{P}$ & $\begin{array}{c}\text { P } \\
\text { losses } \\
\%\end{array}$ \\
\hline
\end{tabular}

\begin{tabular}{|c|c|c|c|c|c|c|}
\hline $0 \%$ & 42.12 & 0 & 42.12 & 0 & 42.12 & 0 \\
$25 \%$ & 33.66 & 20.09 & 31.7 & 24.74 & 28.7 & 31.86 \\
$50 \%$ & 24.12 & 42.73 & 21.92 & 47.96 & 21.53 & 48.88 \\
$75 \%$ & 12.55 & 70.2 & 21 & 50.14 & 17.93 & 57.43 \\
$100 \%$ & 0.085 & 99.8 & 18.2 & 56.8 & 14.32 & 66 \\
\hline
\end{tabular}

Case I. In this case, horizontal string was shaded by $25,50,75,100 \%$ respectively, under radiation changed from 200 to $1000 \mathrm{~W} / \mathrm{m}^{2}$. The results illustrated in Figure. 6, it can be notice that when the radiation reducing, the power output reducing. From these results, power (P) and power losses (P loss $\%$ ) values at $500 \mathrm{~W} / \mathrm{m} 2$ are presented in Table 2 . In the first case, it can be seen that the power output at no shading ( $0 \%$ shading) is $42.12 \mathrm{~W}$, with increasing shading area, the power were decrease until reaches to $0.085 \mathrm{~W}$ at $100 \%$ shading area. This means that the power decreased by $99.8 \%$ in compared with its value at no shading conditions.

Case II. Vertical string shaded applied as previous case and the results explained in Figure7. Table 2. Explained the results of this case, the power output decreased from $42.12 \mathrm{~W}$ at no shaded area to $18.2 \mathrm{~W}$ at $100 \%$ shaded area. In comparison with power at no shading, it means that the power output dropped by $56.8 \%$ at $100 \%$ shaded area.

Case III In this case single cell shaded was applied as the previous cases, the result clarified in Figure 8. the power at no shading area is $42.12 \mathrm{~W}$, and then dropped to $14.32 \mathrm{~W}$ at $100 \%$ shading area. This mean that power decreased by $31.86,48.88,57.43$ and $66 \%$ as the shaded area of cell increased from $0 \%$ to $100 \%$, as compared With power at no shading condition.

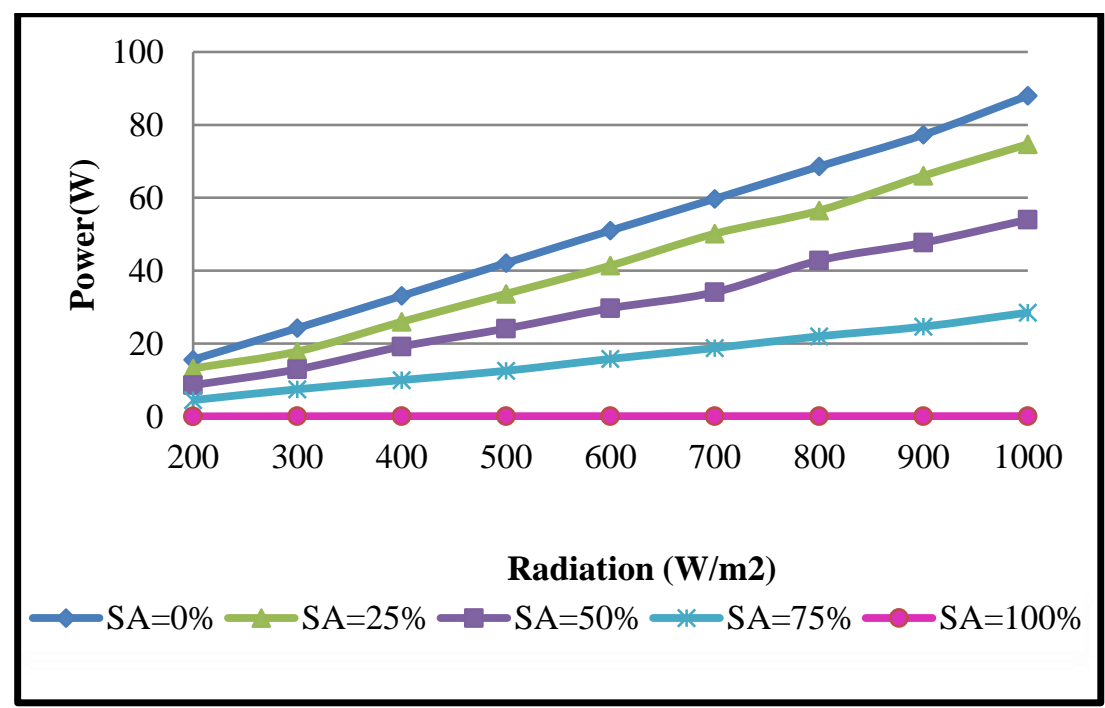

Figure 6: Power output at different percentage of horizontal shading with different radiation levels. 


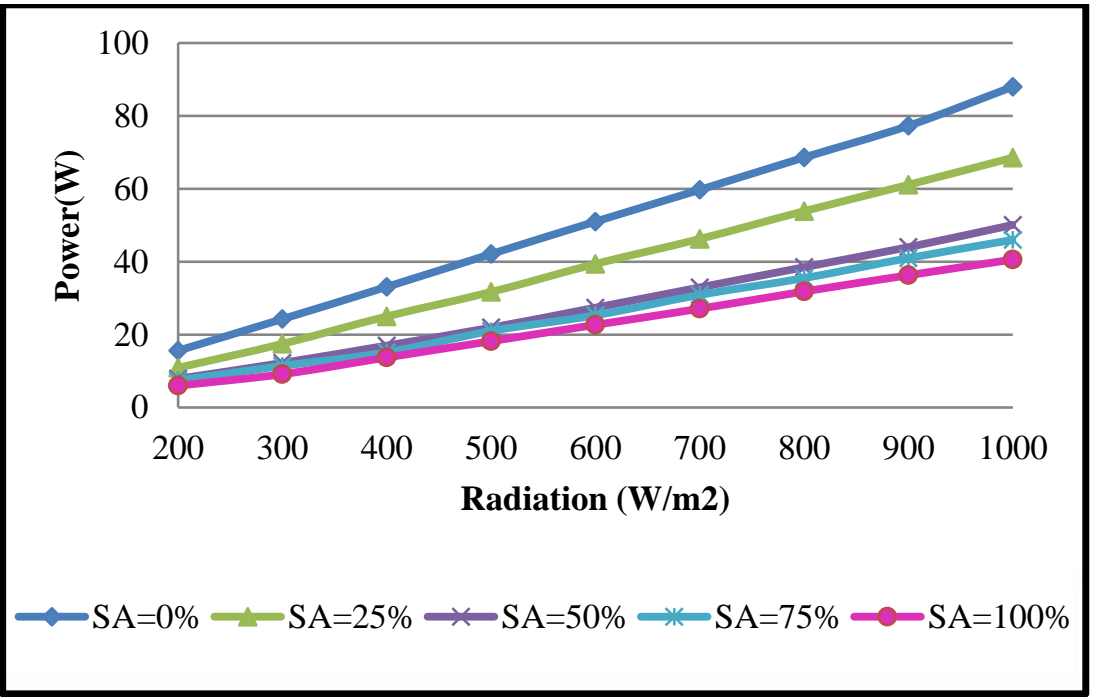

Figure 7: Power output at different percentage of vertical shading with different radiation levels.

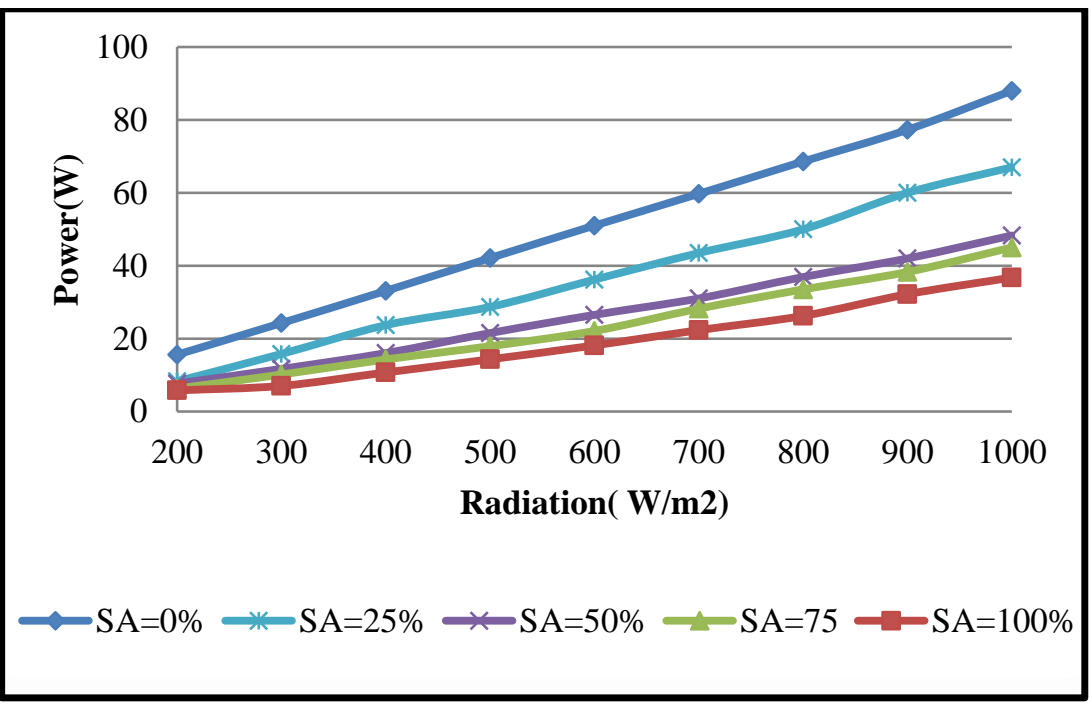

Figure 8: Power output at different percentage of single cell shading with different radiation levels.

\subsection{Partial shading effect on efficiency}

Efficiency of panel as a function of radiation under partial shading condition for horizontal, vertical and single cell has been illustrated in Figures 9, 10 and 11 respectively. It can be observed that in each case of shading when radiation level increased, the efficiency increased. In addition, increasing shading area leads to decrease the efficiency of the panel.

In case one, the effect of shading on efficiency illustrated in Figure 9. Table 3 explained the results of this case, it can be observed that at $500 \mathrm{~W} / \mathrm{m}^{2}$ radiation level, efficiency were $12.55 \%$ at no shading and dropped to $0.026 \%$ at $100 \%$ horizontal shading string. This means that efficiency decreased by $99.8 \%$ in comparison with value at no shading. In the second case, it can be noticed from Figure 10 that the efficiency dropped from $12.55 \%$ at no shading to $5.425 \%$ at $100 \%$ vertical shading string. The same Figures showed that efficiency decreased by $56.77 \%$ in compared to the efficiency at no shading condition. While, in the last case, the efficiency decreased from $12.55 \%$ at no shading to $100 \%$ respectively. This means that efficiency decreased by $65.98 \%$ at $100 \%$.

Table 3: Efficiency and efficiency Loss value of shading.

\begin{tabular}{|c|c|c|c|c|c|c|}
\hline $\begin{array}{c}\text { Shading } \\
\text { Area }\end{array}$ & \multicolumn{2}{|c|}{$\begin{array}{c}\text { Horizontal } \\
\text { string Shading- } \\
\text { Case I }\end{array}$} & \multicolumn{2}{|c|}{$\begin{array}{c}\text { Vertical string } \\
\text { Shading- Case } \\
\text { II }\end{array}$} & \multicolumn{2}{|c|}{$\begin{array}{c}\text { Single cell } \\
\text { Shading- Case } \\
\text { III }\end{array}$} \\
\hline SA & $\eta$ & $\begin{array}{c}\eta \text { losses } \\
\%\end{array}$ & $\eta$ & $\begin{array}{c}\eta \text { losses } \\
\%\end{array}$ & $\eta$ & $\begin{array}{c}\eta \text { losses } \\
\%\end{array}$ \\
\hline $0 \%$ & 12.55 & 0 & 12.55 & 0 & 12.55 & 0 \\
$25 \%$ & 10.03 & 20.08 & 9.44 & 24.78 & 8.55 & 31.78 \\
$50 \%$ & 7.2 & 42.63 & 6.53 & 47.97 & 6.41 & 48.92 \\
$75 \%$ & 3.74 & 70.19 & 6.25 & 50.2 & 5.34 & 57.45 \\
$100 \%$ & 0.026 & 99.8 & 5.43 & 56.77 & 4.27 & 65.98 \\
\hline
\end{tabular}




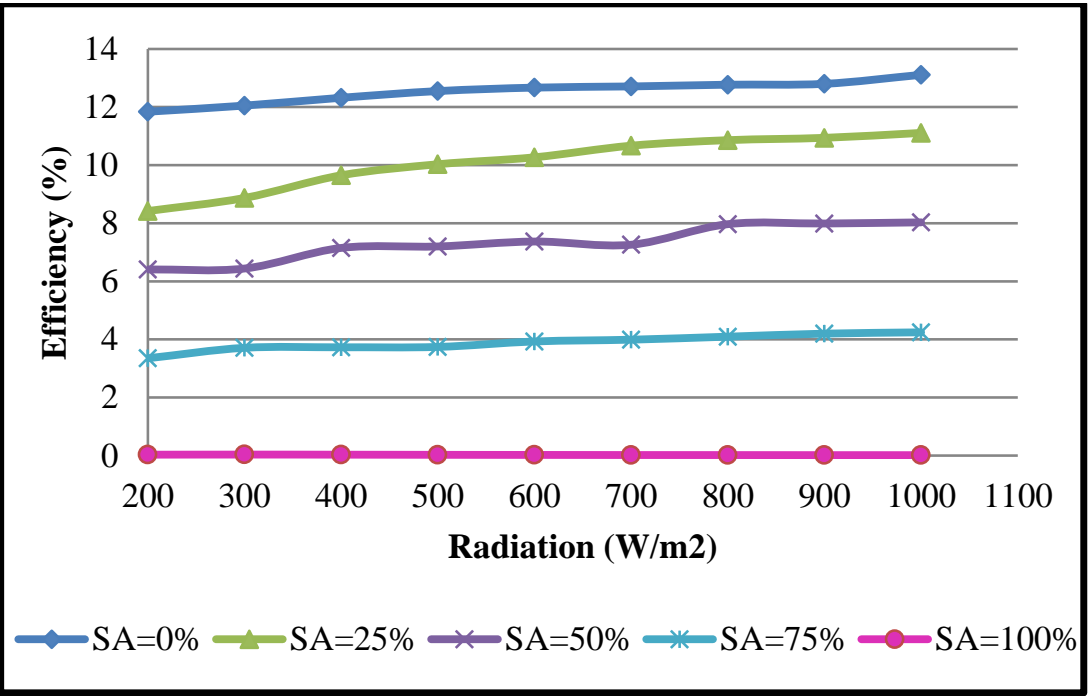

Figure 9: Efficiency versus different irradiation levels at different percentage of horizontal string shading

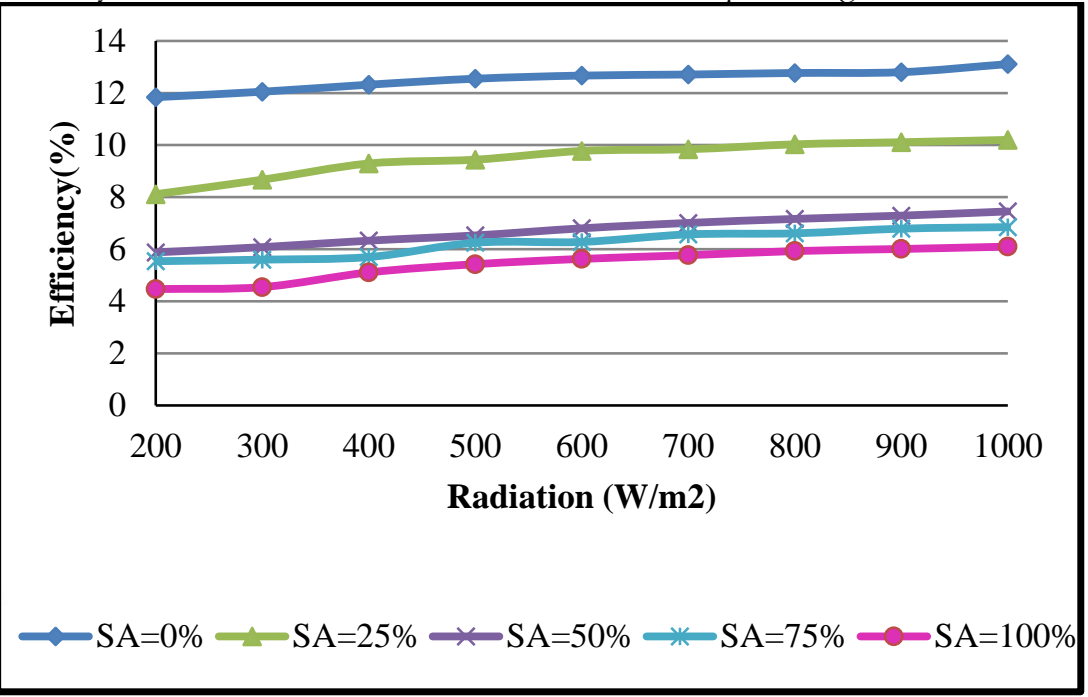

Figure 10: Efficiency versus different irradiation levels at different percentage of vertical string shading

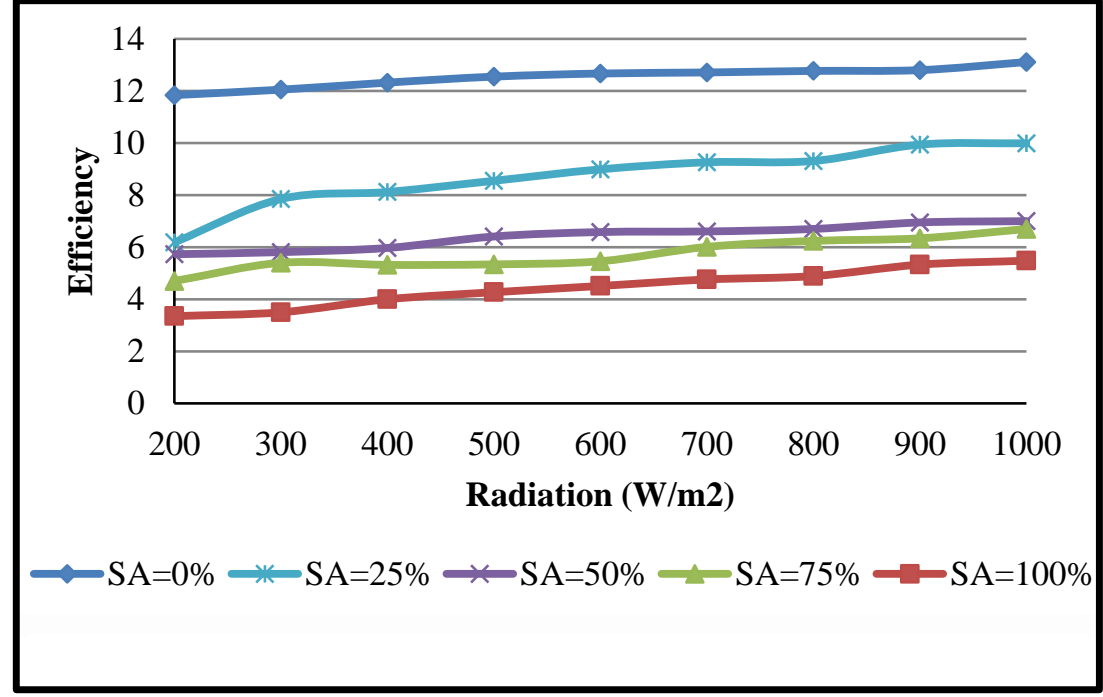

Figure 11: Efficiency versus different irradiation levels at different percentage of single cell shading.

By comparison the power output and efficiency of these cases at percentage of shading area $(100 \%)$ and variable radiation, it can be notice that horizontal shaded string is more impact as illustrated in Figure 12. It was observed that the power output and efficiency were dropped from $0.098,40.6$ and $36.75 \mathrm{~W}$ and at $\mathrm{G}=1000 \mathrm{~W} / \mathrm{m}^{2}$, to $0.0414,6$ and $5.8 \mathrm{~W}$ at $\mathrm{G}=200 \mathrm{~W} / \mathrm{m}^{2}$ for the first, second and third cases respectively. 


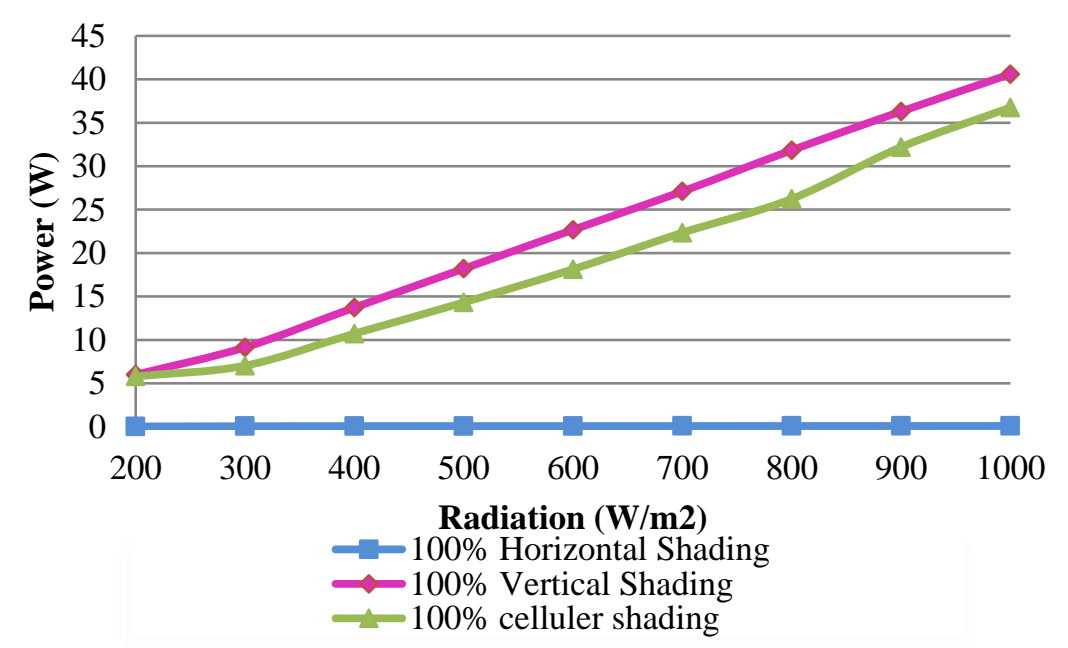

Figure 12: Power output at deferent cases with different radiation levels.

Among these cases, the horizontal shading profile has more influence on power and efficiency as shown in because it influences whole panel subsections. Therefore, more experiments have been carried out to explain it's impact on electrical characteristics (Isc, Voc, Im, Vm, Pm, F.F and $\eta$ ). Transparent material which has 30\% shading ratio, used to shade whole panel horizontally by $20,40,60,80$, and $100 \%$ of shaded area respectively. Figures 13 a, b, c, d and e. clarified the electrical characteristics at $800 \mathrm{~W} / \mathrm{m}^{2}$ radiation level with different shaded area. It has noticed that with increase the shaded area, Voc and Isc decrease and consequently, $\mathrm{Vm}$ and Im decrease. Figures $13 \mathrm{a}, \mathrm{b}$ showed that at $0 \%$ shading area, the value of Isc and Im are 4.14 and 3.88A respectively, whereas the $\mathrm{Voc}$ and $\mathrm{Vm}$ are 21.89 and $19.7 \mathrm{~V}$ respectively. In addition, at $100 \%$ shading condition, Isc and Im were 2.56 and $2.3 \mathrm{~A}$ respectively; however, Voc and Vm were21.2, $18 \mathrm{~V}$ respectively. The Isc and Im dropped by 1.58 and $1.58 \mathrm{~A}$ which were 38.16 and $40.72 \%$ less than the initial state $(0 \%$ shading area). Moreover, the $\mathrm{Voc}$ and $\mathrm{Vm}$ fell $0.69 \mathrm{~V}$ and $1.7 \mathrm{~V}$ which were 3.15 and $8.63 \%$ less than the initial state. Figure 13c. Illustrated impact of shading area increase on power output, at no shading, the power was 68.6W, with increase the shading area, the power decrease significantly. However, at $100 \%$ shading condition, the power dropped to 41.4 which is $39.65 \%$ less than the value at initial state. Another electrical parameter (F.F) was adversely effected by shading. Figure 13 d shows that F.F at no shading is 0.842 , with increasing the shaded area; this parameter will decreased until reach to 0.771 at $100 \%$ shading area. Which mean that it dropped by $8.43 \%$ in comparison with initial state ( $0 \%$ shading area). The efficiency of module behaves with increasing shading area illustrated in Figure 13e. In this figure, the efficiency at no shading and $100 \%$ shading area were
12.77 and $7.71 \%$ respectively. Which mean that the reduction is $39.62 \%$

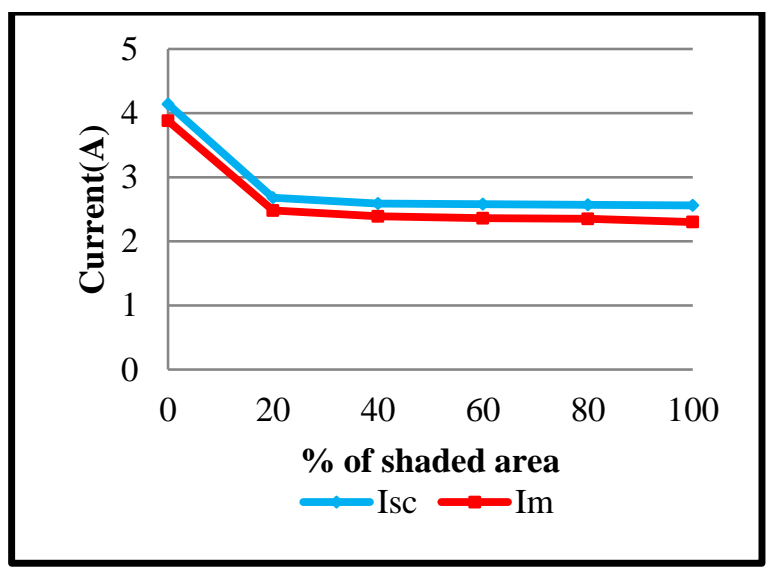

Figure 13 a: Short circuit current and maximum current versus different module shaded area at constant irradiation levels of $800 \mathrm{~W} / \mathrm{m} 2$.

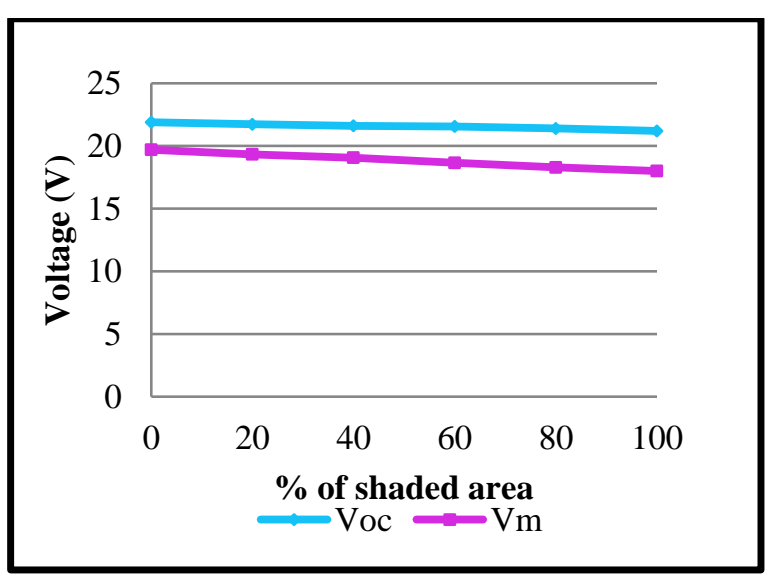

Figure 13 b: Open circuit voltage and maximum voltage versus different module shaded area at constant irradiation levels of $800 \mathrm{~W} / \mathrm{m} 2$. 


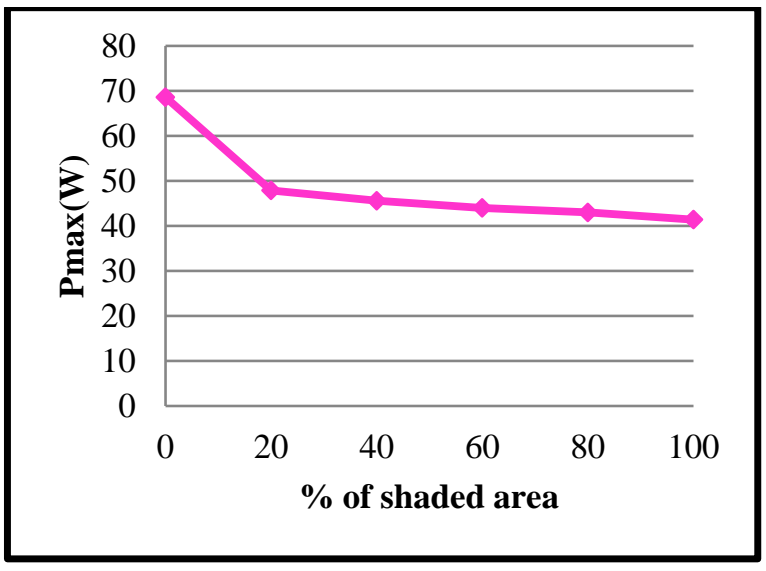

Figure 13 c: Maximum power versus different shading area at constant irradiation levels of $800 \mathrm{~W} / \mathrm{m}^{2}$.

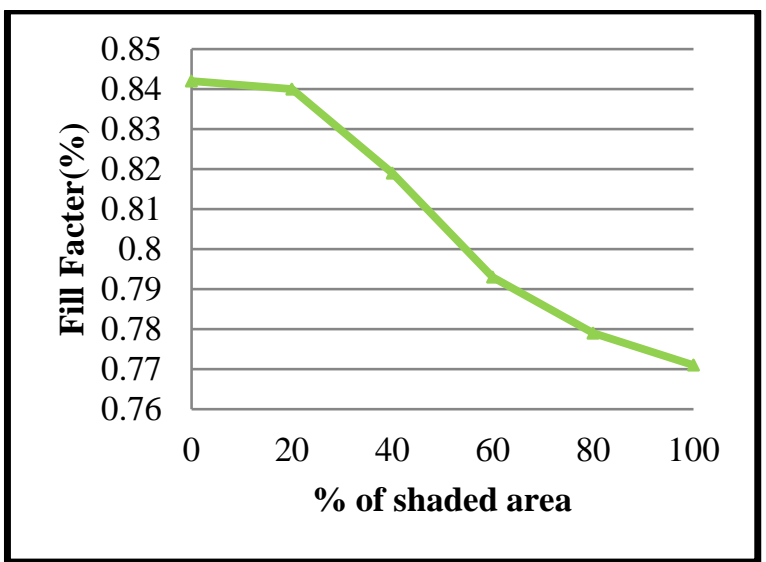

Figure 13 d: Fill factor versus different shading area at constant irradiation levels of $800 \mathrm{~W} / \mathrm{m}^{2}$.

\section{Conclusion}

In summery the large benefits of PV cell made it grown rapidly among various form of renewable energy. Partial shading is one of the most common parameter which reduces the performance of PV system. In this study, different materials with different shading position and different percentage of shading area were applied on monocrystalline solar panel. The results showed that the Photon current under partial shading reduced.

Therefore, Isc and Im reduced and consequently, the output power reduced. The experimental results report that, at $500 \mathrm{~W} / \mathrm{m} 2$ radiation level and $100 \%$ shading condition, the power reduced by 99.8 , 56.8 and $66 \%$ for horizontal, vertical, single cell respectively, in compared with their initial value at no shading condition. Moreover, the efficiency decreased by $99.8,56.77$ and $65.98 \%$ for horizontal, vertical, single cell respectively, in compared with their initial value at no shading condition. Horizontal string shading was more impact on power and efficiency in compared with vertical string and single cell shadings. In addition, when transparent material used to shading whole panel horizontally, Im decreased by $36.08,38.4,39.17,39.43,40.72 \%$ for $20,40,60,80$, $100 \%$ shaded area respectively. In addition, at the previous shading area, the $\mathrm{Vm}$ little effected by shading, it dropped by $1.8,3.2,5.28,7.15,8.6 \%$. Moreover, the power reducing by 44.94, 47.58, $49.42,50.57,52.4 \%$ in compared with their initial values at no shading condition( $0 \%$ shading area).

\section{Acknowledgement}

The authors gratefully acknowledge to the Staff of Al-Mansour State Company for providing the effort, advice and knowledge during the entire period of this work.

\section{References}

[1] Y. Chen, Y. Wu, C. Song and Y. Chen., "Design and implementation of energy management system with fuzzy control for DC microgrid systems," Power Electronics, IEEE Transactions, Vol. 28, No. 4, pp. 1563-1570, 2013.

[2] S. Rahman and H. Abdul Rahman, "Use of Photovoltaics in Microgrid as Energy Source and Control Method using MATLAB/Simulink." International Journal of Electrical and Computer Engineering (IJECE),Vol.6 ,No. 2, pp. 851-858, 2016.

[3] D. thakur, A. arnav, A. datta, E.V.V Ramanamurthy, "A Review on Immersion System to increase the efficiency of Solar Panels," International Journal of Advanced Research, vol. 4, pp. 312-325, 2016.

[4] F. Fadliondi, H. Isyanto, B. Budiyanto., "Bypass Diodes for Improving Solar Panel Performance," International Journal of Electrical and Computer Engineering (IJECE), Vol. 8, No. 5, October 2018, pp. 2703-2708.

[5] A. Fudholi, M. F. Musthafa, A. Ridwan, R. Yendra, A. P. Desvina, Rahmadeni, T. Suyono and K. Sopian "Energy and exergy analysis of air based photovoltaic thermal (PVT) collector: a review," International Journal of Electrical and Computer Engineering (IJECE), Vol. 9, No. 1, , pp. 109 117, 2019.

[6] T. Ahmad, S. Sobhan, Md. F. Nayan, "Comparative Analysis between Single Diode and Double Diode Model of PV Cell: Concentrate Different Parameters Effect on Its Efficiency," Journal of Power and Energy Engineering, vol. 4, pp. 31-46, 2016.

[7] A. Ndiaye, Cheikh M. F. Kébé, Pape A. Ndiaye, Abdérafi Charki, Abdessamad Kobi and Vincent Sambou, "Impact of dust on the photovoltaic (PV) modules characteristics after an exposition year in Sahelian environment: The case of Senegal," International Journal of Physical Sciences, vol. 8, pp. 1166-1173, 2013. 
[8] M. C. Alonso-Garcia, J. M. Ruize and W. Herrmann, "Computer simulation of shading effects in photovoltaic arrays," Renewable energy. Vol.31, No.12, pp. 1986-1993, 2006.

[9] A. Kovach and J. Schmid, "Determination of energy output losses due to shading of buildingintegrated photovoltaic arrays using a raytracing technique," Solar Energy, vol. 57, no. 2, pp. 117124, 1996.

[10] M. C. A. García, W. Herrmann, W. Bohmer, and B. Proisy, "Thermal and electrical effects caused by outdoor hot-spot testing in associations of photovoltaic cells," Progr. Photovolt., Res. Appl., vol. 11, no. 5, pp. 293-307, 2003.

[11] R. Ahmad, A. F. Murtaza, H. A. Sher, U. T. Shami, S. Olalekan, "An analytical approach to study partial shading effects on PV array supported by literature ," Renewable and Sustainable Energy Reviews, vol.74, pp.721-732, 2017.
[12] S. Daliento, F. Di Napoli, P. Guerriero, V. d'Alessandro, "A modified bypass circuit for improved hot spot reliability of solar panels subject to partial shading," Solar Energy,Vol. 134, pp. 211-218, 2016.

[13] H. Khaing, Y. Liang, N. Htay, J. Fan, "Characteristics of Different Solar PV Modules under Partial Shading," International Journal of Energy and Power Engineering, Vol. 8, No. 9, 2014.

[14] F. Bayrak, G. Ertürk , H. F. Oztop, "Effects of partial shading on energy and exergy efficiencies for photovoltaic panels," Journal of Cleaner Production, 164, pp. 58-69,

[15] M. A. Al Mamun, Md Hasanuzzaman , J. Selvaraj," Experimental investigation of the effect of partial shading on photovoltaic performance," IET Renewable Power Generation, Vol. 11, Iss. 7, pp. 912-921, 2017. 